\title{
Evidence-Based Identification of the Most Important Livestock Related Zoonotic Diseases in Kampala, Uganda
}

\author{
Kohei MAKITA $^{1) *}$, Eric M. FÈVREE), Charles WAISWA ${ }^{3)}$, Winyi KABOYO ${ }^{4)}$, Mark C. EISLER ${ }^{1)}$ and \\ Susan C. WELBURN ${ }^{1)}$ \\ ${ }^{1)}$ Centre for Infectious Diseases, Division of Pathway Medicine, School of Biomedical Science, College of Medicine and Veterinary \\ Medicine, University of Edinburgh, Summerhall Square, Edinburgh, EH9 1QH, ${ }^{2}$ School of Biological Sciences, Ashworth Laboratories, \\ University of Edinburgh, Kings Buildings, Edinburgh, EH9 3JT, U.K., ${ }^{3)}$ Faculty of Veterinary Medicine, Makerere University, P.O. Box \\ 7062, Kampala and ${ }^{4}$ Ministry of Health, Kampala, Uganda
}

(Received 9 February 2011/Accepted 22 March 2011/Published online in J-STAGE 5 April 2011) ABSTRACT. Urban and peri-urban livestock farming in developing countries plays an important role in food security in cities; however it
brings with it zoonotic risks. The present study was conducted to identify the most important livestock farming-related zoonotic diseases
among the human population in urban and peri-urban areas of Kampala, Uganda and to assess the risks from such farming. A framework
for identifying livestock farming-related significant zoonoses was developed. The process consisted of screening of medical record sum-
maries for zoonotic diagnoses, selection of the zoonoses which are related to livestock farming, case estimation of the identified zoonoses
and evidence-based reassurance of the importance of diseases. Medical records in the Mulago National Referral Hospital were used for
the analysis. Leaders and residents of 75 Local Councils (LC1s: villages; 48 urban, 11 peri-urban and 16 rural) randomly selected in
Kampala were interviewed for information regarding livestock farming systems, value chains and use of medical service units. Twelve
zoonoses were identified in the screening and four out of them were related to livestock farming: animal sourced food-borne gastroen-
teritis, brucellosis, Taenia solium neuro-cysticercosis and Mycobacterium bovis tuberculosis. Livestock farming, value chain and severity
of the diseases confirmed that all four diseases were important. Poor geographical correlation between animals in peri-urban and rural
areas and patients in urban areas suggested that the majority of these zoonoses were caused by informally-marketed foods.
KEY wORDS: brucellosis, food-borne, uganda, urban, zoonoses.

Rapid expansion of cities due to the continuous dynamic growth of urban populations is a uniform phenomenon of developing countries, and by 2025 it is estimated that over $50 \%$ of the population in those countries will reside in or around cities [9]. To support growing city populations, urban and peri-urban agriculture (UPA) has become an integral part of the development agenda [10]. UPA plays a critical role in employment, improvement of childhood nutrition status [29] and food security [8, 39]. However, UPA also presents public health risks, including zoonotic disease transmission [14]. Zoonoses are defined as "diseases and infections that are naturally transmitted between vertebrate animals and man" [43]. Intense competition for natural resources such as land and water is another challenge for the sustainability of urban agriculture [8]. Policy and regulation related to UPA, specifically whether to promote or prohibit, has been discussed for more than a decade and two principal ideas dominate: (i) permitting the urban poor the widest possible range of opportunities to piece together their livelihoods and (ii) enhancement of ruralurban interactions [8]. The roles of public health research in this issue are therefore clear, although still broad: better understanding of public health risks from UPA for the better

\footnotetext{
* Correspondence to: Makita, K., School of Veterinary Medicine, Rakuno Gakuen University, Ebetsu, Hokkaido 069-8501, Japan and International Livestock Research Institute (ILRI), P.O. Box 30709, Nairobi, Kenya.

e-mail:kmakita@rakuno.ac.jp
}

management of such agriculture.

In Kampala, the formal economy was severely damaged by the "war of economic independence" during the regime of Idi Amin between 1971 and 1979 [29] and urban agriculture became popular in order to secure food. Due to the widespread practice of urban agriculture, there was no malnutrition observed in Kampala during 1980s civil war and 1990s structural adjustment policies [23]. However, officially, urban agriculture has been illegal until recently, despite its importance for many Kampala households [23]. Gradual positive change towards urban agriculture was facilitated by a global research project, Urban Harvest, lead by the Consultative Group on International Agricultural Research (CGIAR), of which Kampala was one of the study sites $[21,23]$. This project in Kampala was conducted between 2002 and 2004 and described the advantages of UPA such as food security [36] and nutrition [48] as well as the public health risks such as crops contaminated with heavy metal [32], vegetables grown on untreated sewagewatered soil [38] and zoonoses from chicken rearing [7] and dairying $[16,17]$. This study concluded (i) that rearing chicken was not a risk factor for diarrhoea and (ii) raw milk carried Brucella (44\% of milk samples from households was positive in milk ring test) and Escherichia coli O-157: H7 $(1.8 \%)$. This research resulted in the participatory review of Ordinances related to urban farming which eventually passed into law in 2006 [23]; urban agriculture is now legal. The key message from the Urban Harvest studies was that 
urban agriculture should be allowed but research and technical support are needed to reduce public health risks.

The present research project was conducted in Kampala between 2005 and 2007 to understand public health risks of urban and peri-urban livestock farming, using a different approach from the Urban Harvest studies. Urban Harvest focused on the zoonotic risks from popular livestock farming in Kampala: dairy and poultry farming, from surveys conducted in purposively selected parishes and households. The present study tried to elucidate the important livestock farming-related zoonoses for human populations - not only for farming populations - caused by urban and peri-urban livestock farming by screening medical records in the largest national referral hospital in Uganda and by considering the risks identified through understanding of the characteristics of livestock farming and its marketing. A rigorous stratified random sampling of villages (Local Council I, the smallest administrative unit) was used for the generation of livestock and marketing data; Uganda has an administrative system consisting of 5 levels: District (LC5), County (LC4), Sub-County (LC3), Parish (LC2) and zone/village (LC1) [41]. This approach is 'selecting from the universe of hazards' [16] but we narrowed the hazards by understanding the risks. For disease prioritization exercises, several measurements of disease burden such as case counting [13] and disability-adjusted life year (DALY) [46] are used in the world. Even in Europe semi-quantitative methods are currently used due to the multi-dimension problem of priority settings [18]. We quantify disease burden by case estimation and qualitatively assess the importance of disease by risk. The results have limitations due to the low availability of data and non-specific nature of clinical diagnosis; however the information will inform a better understanding of public health risks from livestock farming in Kampala, which will be useful to allocate limited resources for the researches and interventions of diseases, which could often be neglected due to the under reporting.

\section{MATERIALS AND METHODS}

Study site: This study was conducted in the $75 \mathrm{LC} 1 \mathrm{~s}$ (48 urban, 11 peri-urban and 16 rural) in the Kampala economic zone (Fig. 1). These LC1s were selected using a stratified random sampling (strata: Sub-Counties: LC3s which more than a half of the areas are located in the area between 5 and $20 \mathrm{~km}$ from the city centre, Nakasero). The degree of urbanisation of the $75 \mathrm{LC} 1 \mathrm{~s}$ (urban, peri-urban and rural) was classified by a combination of interviews and observations using a reported method [25]. The definitions used were (1) urban areas: densely populated areas, (2) peri-urban areas: transition areas from rural to urban with rapid population increase caused by migration from city or town accompanying house construction and (3) rural areas: static areas before urbanisation starts. Medical record surveys were undertaken in the Mulago National Referral Hospital, the largest national hospital in Uganda, located in an urban area of Kampala.

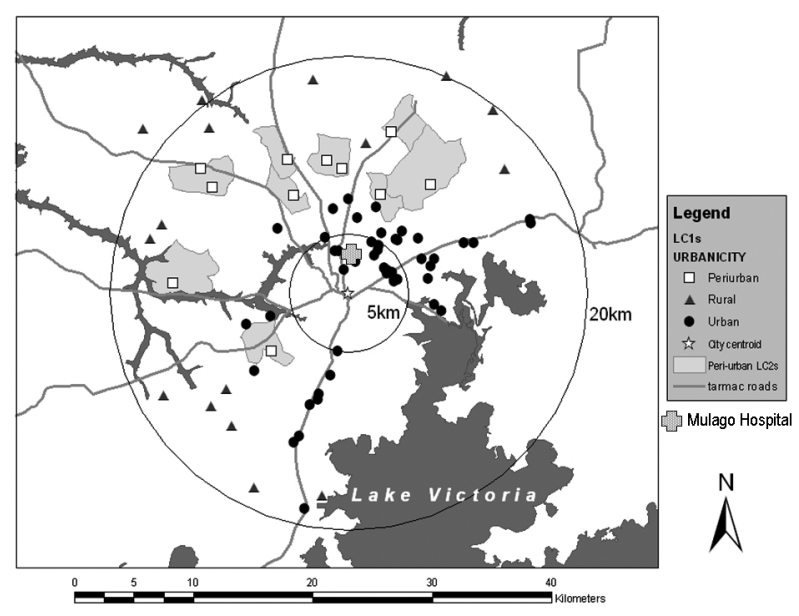

Fig. 1. Map showing the Mulago National Referral Hospital and 75 LC1s (Local Council I) studied in the Kampala economic zone.

Ethical considerations: The ethics of this project were assessed and approved by the Uganda National Council for Science and Technology (UNCST) (reference number A 432). Access to the medical records of Mulago Hospital was granted by the Director General Health Services, Ministry of Health, Uganda.

Case estimation of livestock farming-related zoonoses: Figure 2 shows the framework for quantitative case estimation of livestock farming-related zoonoses in the Kampala economic zone. Case estimation started from screening the Mulago Hospital monthly outpatient medical record summary from March 2005 to February 2006 for zoonotic diagnoses (Fig. 2b). Physicians report diagnosis for outpatients to the Medical Record Division when diagnosis was made based on clinical or laboratory tests. When diagnosis was not made, either the main symptom was recorded or a case was reported as 'not diagnosed' (personal communication of a physician). From the monthly summaries, the numbers of cases for the twelve months were added up for each diagnosis/ symptom. Each diagnosis/ symptom was judged as to whether a zoonotic pathogen(s) could cause it or not using the list of 838 zoonotic pathogens in Taylor et al. [40], the International Classification of Diseases [45], published papers, books and the other internet sources. Non-specific diagnoses which are too difficult to assume zoonotic cause such as fever, cough and pneumonia were excluded from the judgement. There were large numbers of non-diagnosed cases and cases only reporting symptoms that might have included large number of zoonoses; this method has a clear limitation because of this. Another clear limitation is that in the daily activities in Mulago Hospital, causal pathogens are not necessarily determined and we needed to assume the presence of the diseases of local importance in Uganda reported in literatures, from the zoonotic diagnoses in medical records.

The next step was to exclude zoonoses which were not related to livestock farming (Fig. 2c). The remaining 


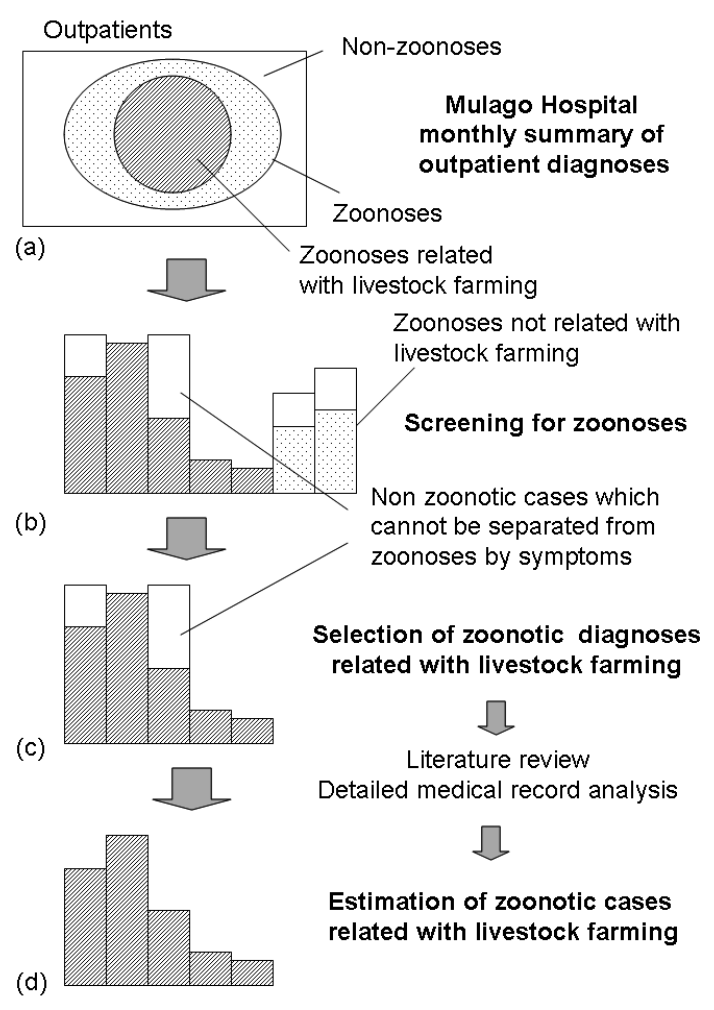

Fig. 2. A schematic framework of quantitative case estimation of livestock farming-related zoonoses in Kampala. (a) A Ven diagram showing Mulago Hospital monthly summary of outpatient diagnoses. (b) Screening for zoonoses. (c) Selection of zoonotic diagnoses related with livestock farming. (d) Estimation of zoonotic cases related with livestock farming. (b), (c) and (d) are conceptual figures and do not represent actual numbers of diagnoses.

zoonoses which appeared to be moderately to highly prevalent were assessed further either from the specialised department or by tracing back to an outpatient registration book for individual data. The numbers of cases were estimated using both the monthly reports and the individual data (Fig. 2d). From individual data, the LC1 where patients resided were collected but personal data or detailed addresses were not collected. For brucellosis, the plate agglutination test (sensitivity and specificity: 0.771 and 0.960 [15]) results between June 2004 and May 2006 collected at the Department of Microbiology were used and the number of true cases among Mulago Hospital outpatients was estimated using a modification of an established stochastic risk assessment model [26]. It was found that Mulago Hospital lacked the test kits for 11 out of the 24 months studied. Therefore, the numbers of diagnoses in the 13 months when the test kits were available were served for bootstrapping to estimate the number of true cases. Monte Carlo simulation was run for 10,000 iterations using @Risk (Palisade).

Identification of livestock farming-related important zoonoses: The importance of zoonoses related to livestock (a)
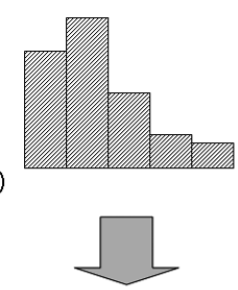

(b)
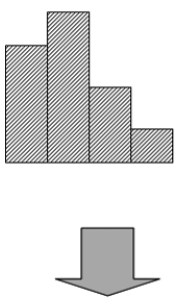

(c)

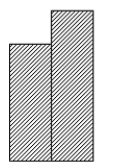

Fig. 3. A schematic framework of identification of the most important livestock farming-related zoonoses. (a) Estimated cases of zoonoses related with livestock farming. (b) Evidence-based reassurance of importance of the diseases. (c) Identification of the most important livestock farming-related zoonoses in Kampala. (a), (b) and (c) are conceptual figures and do not represent actual numbers of diagnoses.

farming was confirmed using evidence from livestock farming systems and value chain analysis (a value chain is a chain of activities or elements of a supply chain that together make up a complete system - in this case the chain supplying livestock products) observed from the Local Council Survey (Fig. 3). Levels of urbanisation of the LC1s where patients resided were classified using the method above-mentioned in the Study site section and the numbers of patients from each level of urbanisation were counted to examine the association between urban and peri-urban livestock farming and disease. Finally, severity of the zoonoses was qualitatively assessed (severe: life threatening or causing longterm negative effects to health and livelihood of the patients, moderate: non-life-threatening and causing moderate shortterm negative effects, and low: non-life threatening and causing minor negative effects) from literatures to identify the important livestock farming-related zoonoses in the Kampala economic zone.

Local council survey: Key-informants interviews with Local Council (LC1) leaders and residents were conducted in the selected LC1s, using a structured questionnaire. Encountered residents who had lived in the LC1 for at least 3 years were asked to participate in the interviews together with the LC1 Leader. One questionnaire was provided for each $\mathrm{LC} 1$ and the responses gained consensus by the partic- 
ipants were recorded. The key-informant interviews concerned 1) characteristics of livestock farming, 2) value chains of livestock products to examine risk factors for zoonotic infections and 3) identification of health service units most commonly used by the population in Kampala. Livestock farming systems were observed in each LC1 for triangulation [27].

Analysis of livestock data: Questions covered the total number of households, number of households keeping animals and poultry, number of large scale farms and numbers of their animals (birds) and average number of animals (birds) in small scale farms. Large scale farms were defined for the present study as: (i) dairy farms with $>10$ cows, (ii) indigenous breed cattle farms with $>50$ cattle, (iii) pig farms with $>50$ pigs or $>10$ sows, (iv) goat farms with $>30$ goats, (v) sheep farms with $>20$ sheep and (vi) layer and broiler farms with $>500$ birds. The number of households selling to trading centres and markets and the names of the sales destinations were recorded.

The overall percentages of households keeping each livestock species in urban, peri-urban, and rural LC1s were calculated. Also in order to take into account the variance of the proportions of households keeping livestock among LC1s in the same urbanicity group, the proportions of households keeping each livestock species in LC1s were compared among urban, peri-urban and rural LC1s using a GLM with binomial errors. Herd size was compared using GLM with Poisson errors. The number of animals per thousand households (i.e., animal density compared with human density), was analysed using a one-way ANOVA after transforming data based on Box-Cox transformations [4]. Many urban LC1s lacked certain livestock species for which data were skewed and, in this case, the proportions of LC1s with the livestock species were compared. When LC1s in more than two urbanicity groups did not have certain animals or birds for which data were skewed, the numbers of animals per thousand households were compared visually from Box and Whisker plots. These data of the LC1s were not aggregated within each urbanization group in the analyses in order to keep information at the LC1 level.

The numbers of farming households selling to each category of sales destination were summed up for each level of urbanicity. Sales destinations of livestock and their products in urban, peri-urban and rural areas were analysed using Chi-square test or Fisher's Exact Test.

\section{RESULTS}

Selection of the hospital to study: The choices of health service unit were studied in $73 \mathrm{LC} 1 \mathrm{~s}$ ( $2 \mathrm{LC} 1 \mathrm{~s}$ were not sure about people's health seeking behaviour). People mostly used Mulago Hospital (55\%, 95\% CI: 43-66, 40/73), especially when they were seriously ill (90\%, 95\% CI: 81-96, 66/73). Mulago Hospital received patients from all urbanicity groups (urban: 27/46, 59\%; peri-urban: 7/11, 46\%; rural: $6 / 16,38 \%$ ) and low-income groups (slum area dwellers) particularly used Mulago Hospital (5/6, 83\%). From these results, Mulago Hospital was considered the most appropriate source of data for the present research since it captured respondents from all income groups across all levels of urbanisation.

Screening of monthly summary records for zoonoses: Over a 12 months period between March 2005 and February 2006, 62,671 outpatients were examined and 554 diagnoses/ symptoms were given. The most common diagnoses were infectious diseases. Malaria was the most common diagnosis $(17,951,28.6 \%$ of total outpatients) among 554 diagnoses/ symptoms.

Diarrhoea, dysentery, enteritis, gastroenteritis and colic and GI parasitic diseases were combined and named as GI infections (see Table 1) [33]. Candidiasis, Tinea (ringworm), Tinea capitis (scalp ringworm), fungal infection and fungal nail were combined as fungal infections. Tuberculosis was served as possible $M$. bovis TB. M. bovis is commonly isolated from cervical adenitis [20] but the location of the diagnosis 'adenitis' in a body was not indicated in the medical record summaries and we did not include them. Brucellosis, BAT (abbreviation of Brucella agglutination test), orchitis, epididymitis and scrotal swelling [5] were combined as possible brucellosis. Epilepsy, seizure, spasm and fits were combined and named as possible neuro-cysticercosis (NCC) [42], considering the local importance, although none of the diagnoses determined the presence of pathogen in patients. As a result, 12 zoonoses were identified combining 42 diagnoses, and they accounted for 5,841 $(9.3 \%)$ out of 62,671 outpatients. GI infections were the most common diseases with 3,500 cases; however at this stage a large number of non-zoonotic diagnoses was included in them.

Selection of livestock farming-related zoonoses: Considering relationships with livestock farming, fungal infections, cellulitis, rabies [12], Hepatitis A [44], elephantiasis, schistosomiasis and encephalitis were excluded. Hepatitis E causes food-borne infection sporadically in non-endemic zones [28] but waterborne outbreak is more significant in endemic zones [34], therefore it was excluded from the disease list related with livestock farming. Tetanus was also excluded because Clostridium tetanus is universally in soils and infection usually occurs through dirty wounds or cuts [47]. Finally, GI infections, M. bovis TB, brucellosis and NCC remained.

Case estimation of livestock farming-related zoonoses: In the United States of America, it is estimated that 76 million food-borne illnesses occur each year [30] and the national estimate of acute gastroenteritis was 195 million (19981999) [19]. We estimated the proportion of GI infections due to food-borne illness from these studies (76 million/195 million $=39 \%$ ) and then estimated the proportion of animalsource food-borne illnesses out of all food borne illnesses using a published table [1] and it was estimated to be $88 \%$ including complex food and infected food handlers. Therefore the number of animal source food-borne cases in Mulago Hospital was estimated to be 1,201 (see Table 2). Brucellosis cases among Mulago Hospital outpatients were 
Table 1. Potential zoonoses and their possible zoonotic cause with the aggregated numbers of cases in Mulago Hospital (March 2005 to February 2006)

\begin{tabular}{|c|c|c|c|c|}
\hline Rank & Zoonoses & Zoonotic cause & Cases & Diagnoses synthesized \\
\hline 1 & Zoonotic GI infections & $\begin{array}{l}\text { Viruses, bacteria and } \\
\text { protozoa }\end{array}$ & 3,500 & $\begin{array}{l}\text { Gastroenteritis }(1,562) \text {, enteritis }(754) \text {, } \\
\text { gastritis }(272) \text {, diarrhoea (89), dysentery (276), } \\
\text { helminthiasis }(543) \text {, hook worm (1), } \\
\text { trichuriasis (1), colic (1), amoebiasis (1) }\end{array}$ \\
\hline 2 & Fungal infections & Many fungi & 859 & $\begin{array}{l}\text { Candidiasis (597), Tinea (ringworm) (210), } \\
\text { Tinea capitis, (scalp ringworm) (20), } \\
\text { fungal infection (25), fungal nail (7) }\end{array}$ \\
\hline 3 & $\begin{array}{l}\text { M. bovis } \\
\text { tuberculosis }\end{array}$ & Mycobacterium bovis & 797 & Tuberculosis (797) \\
\hline 4 & Brucellosis & $\begin{array}{l}\text { Brucella abortus, } \\
\text { B. melitensis, } \\
\text { B. suis, B. canis }\end{array}$ & 293 & $\begin{array}{l}\text { Brucellosis (187), BAT (63), orchitis (41), } \\
\text { epididymitis (1), scrotal swelling (1) }\end{array}$ \\
\hline 5 & $\begin{array}{l}\text { Neuro- } \\
\text { cysticercosis }\end{array}$ & Taenia solium & 196 & $\begin{array}{l}\text { Epilepsy (135), spasm (45), fits (14), } \\
\text { seizures (2) }\end{array}$ \\
\hline 6 & Cellulitis & $\begin{array}{l}\text { Staphylococcus, } \\
\text { Streptococcus }\end{array}$ & 132 & Cellulitis (132) \\
\hline 7 & Rabies & Rabies virus & 25 & Dog bite (18), animal bite (7) \\
\hline 8 & Hepatitis A, E & $\begin{array}{l}\text { Hepatitis A virus } \\
\text { Hepatitis E virus }\end{array}$ & 21 & Hepatitis (20), jaundice (1) \\
\hline 9 & Elephantiasis & $\begin{array}{l}\text { Wuchereria bancrofti, } \\
\text { Brugia malayi }\end{array}$ & 10 & Elephantiasis (10) \\
\hline 10 & Tetanus & Clostridium tetanus & 4 & Tetanus (4) \\
\hline 11 & Shistosomiasis & Schistosoma & 3 & Schistosomiasis (3) \\
\hline 12 & Encephalitis & Encephalitis viruses & 1 & Encephalitis (1) \\
\hline
\end{tabular}

Table 2. Case estimation of livestock farming-related zoonoses among patients visiting Mulago Hospital and qualitative severity assessment of the diseases

\begin{tabular}{|c|c|c|c|}
\hline Zoonoses & Estimated cases & Information used for estimation & Severity \\
\hline $\begin{array}{l}\text { Animal source } \\
\text { food-borne } \\
\text { gastroenteritis }\end{array}$ & 1,201 & $\begin{array}{l}3,500 \times 0.39 \text { (foodborne illness out of acute } \\
\text { gastroenteritis in USA) } \times 0.88 \text { (animal source } \\
\text { related illnesses out of food-borne illness } \\
\text { in England and Wales) }\end{array}$ & $\begin{array}{l}\text { Major cause of } \\
\text { child death: } \\
\text { severe. }\end{array}$ \\
\hline Brucellosis & $\begin{array}{c}678 \\
(90 \% \text { CI: } 628-731)\end{array}$ & $\begin{array}{l}\text { Stochastic estimate of brucellosis in Mulago } \\
\text { Hospital using plate agglutination test } \\
\text { results by a reported method. }\end{array}$ & $\begin{array}{l}\text { Easily missed. } \\
\text { Fever persists. } \\
\text { High economic } \\
\text { impact: severe. }\end{array}$ \\
\hline $\begin{array}{l}\text { M. bovis } \\
\text { tuberculosis }\end{array}$ & $73 \mathrm{~b}$. & $\begin{array}{l}\text { a. Estimation from monthly summary: } 797 \times \\
0.031 \text { (proportion of } M \text {. bovis TB out of } \\
\text { global all TB) }=24.7 \\
\text { b. } 73 \text { of } 86 \text { abdominal tuberculosis patients } \\
\text { admitted in } 2005 \text { in Mulago Hospital were } \\
\text { from Kampala. }\end{array}$ & $\begin{array}{l}\text { Severe and life } \\
\text { thretening. }\end{array}$ \\
\hline $\begin{array}{l}\text { Neuro- } \\
\text { cysticercosis }\end{array}$ & $19-27$ & $\begin{array}{l}\text { Lower estimate: } 135 \text { (epilepsy cases) } \times 0.137=19 \\
\text { Upper estimate: } 196 \text { (possible cases) } \times 0.137=27\end{array}$ & $\begin{array}{l}\text { It can cause } \\
\text { epilepsy: severe. }\end{array}$ \\
\hline
\end{tabular}

estimated to be 678 (90\%CI: 628-731) by a stochastic simulation.

M. bovis TB cases were estimated by two approaches: (i) used TB cases in monthly summary reports - the global esti- mate of proportion of TB due to $M$ bovis out of all TB is $3.1 \%$ [40] and $25 \mathrm{M}$ bovis TB cases were estimated using this proportion; (ii) M. bovis TB cases were estimated from abdominal TB cases found in the TB Ward (73 cases from 
Table 3. Percentages of households keeping livestock in the Kampala economic zone with $95 \%$ confidence intervals

\begin{tabular}{lcccc}
\hline Species & Urban & Peri-urban & Rural & \multicolumn{1}{c}{$P$-value } \\
\hline Improved breed cattle & $0.3(0.1-0.7)$ & $4.5(2.9-7.0)$ & $3.7(1.7-7.8)$ & $\begin{array}{l}\text { U-P: } P<0.001 \\
\text { P-R: } P=0.62\end{array}$ \\
Indigenous breed cattle & $0.2(0.1-0.6)$ & $2.2(1.1-4.2)$ & $10.8(5.3-20.8)$ & $\begin{array}{l}\text { U-P: } P<0.001 \\
\text { P-R: } P<0.001\end{array}$ \\
Pig & $1.4(0.3-6.1)$ & $16.4(6.9-34.1)$ & $16.0(3.9-47.3)$ & $\begin{array}{l}\text { U-P: } P=0.001 \\
\text { P-R: } P=0.97\end{array}$ \\
Goats & & & & U-P: $P=0.005$ \\
Sheep & $0.7(0.2-1.8)$ & $2.9(1.3-6.2)$ & $9.6(3.9-21.9)$ & P-R: $P=0.012$ \\
& & & & U-P: $P<0.001$ \\
Broiler & $0.04(0.0-0.1)$ & $0.7(0.4-1.4)$ & $1.5(0.6-3.6)$ & P-R: $P=0.13$ \\
Layer & & & & $P=0.61$ \\
Indigenous chicken & $2.5(1.0-6.1)$ & $2.8(1.2-6.4)$ & $1.2(0.2-7.2)$ & $P=0.41$ \\
& $0.7(0.2-2.1)$ & $1.3(0.5-3.3)$ & $1.5(0.3-6.1)$ & U-P: $P<0.001$ \\
& $14.6(6.6-29.3)$ & $59.1(40.0-75.9)$ & $71.5(40.5-90.2)$ & P-R: $P=0.41$
\end{tabular}

U-P: $P$-value between urban and peri-urban. P-R: $P$-value between peri-urban and rural.

Kampala economic zone in 2005) - there could be non $M$. bovis cases among them but it was not calculated.

In northern Tanzania, $13.7 \%$ of people with epilepsy were said to be probable or definite NCC [3] and NCC cases were estimated using this figure. Only epilepsy cases were used for the lower point estimate (19 cases) and all possible cases for the upper point estimate (27 cases).

Characteristics of livestock farming: The percentages of the households keeping each livestock species in the 75 LC1s is shown in Table 3. In the LC1s studied, LC1 leaders kept list of all the households within the zones and knew the total number of households. The numbers of households keeping livestock were then answered in each LC1. For all the livestock species other than broilers and layers, the proportion of households keeping animals (birds) in urban areas was significantly lower than in peri-urban areas. The percentages of households keeping broilers $(P=0.61)$ and layers $(P=0.41)$ were not significantly different among urban, periurban and rural areas. Indigenous breed cattle, goats and sheep were kept by a significantly higher percentage of households in rural areas than in peri-urban areas.

Among all the livestock species, indigenous chickens were the most popular species to be kept $-24.3 \%$ of households $(10,912$ of 44,962$)$ in the $75 \mathrm{LC} 1 \mathrm{~s}$ kept, followed by pigs $(4.3 \%)$, broiler $(2.4 \%)$, goats $(1.6 \%)$, indigenous breed cattle $(1.3 \%)$, improved breed cattle $(1.1 \%)$ and layer $(0.9 \%)$. Sheep keeping was rare $(0.2 \%)$; sheep were not regarded as sources of food, but were believed to protect sheep keepers from evil spirits. Herd size did not vary significantly among urban, peri-urban and rural areas for any livestock species.

The number of animals (birds) per thousand households in urban areas was significantly lower than peri-urban areas for all the species other than sheep (the number of sheep was too small to compare). The number of indigenous breed cattle per thousand households in rural areas was obviously greater than in peri-urban areas. On the contrary, that of broiler birds in peri-urban areas was obviously greater than in rural areas.

Value chains of livestock products: The sales destinations of livestock and their products in the Kampala economic zone are shown in Table 4 . The 'improved breed cattle farm' category shows only milk sales. Almost all improved breed cattle farms sold raw milk to nearby trading centres and their neighbours. The modes of milk sales within LC1s were either direct purchase at the farm gate or by a milk trader selling with milk container (can or plastic) on a bicycle. The 11 urban farms which were not selling milk to nearby trading centres or neighbours sold to large contract customers, such as hotels and large markets. Peri-urban improved breed cattle farms sold milk to outside trading centres in significantly higher proportion $(27.0 \%)$ than urban $\left(10.1 \%, \chi^{2}=12.6, \mathrm{df}=1, P<0.001\right)$ and rural farms $\left(9.3 \%, \chi^{2}=15.9, \mathrm{df}=1, P<0.001\right)$.

Over half of urban cattle farms sold cattle to urban abattoirs $(56.0 \%)$ and the other half $(53.8 \%)$ sold to peri-urban abattoirs (multiple choices were allowed). Almost all periurban $(98.6 \%)$ and rural $(100 \%)$ farms sold cattle to periurban abattoirs and they sold also to urban abattoirs (34.7 and $13.2 \%$, respectively). According to the informal interviews with urban abattoirs, cattle are transported from production areas outside the Kampala economic zone, but the present study does not quantify it here.

Pigs were distributed to outside trading centres as well as to the local communities from all levels of urbanicity groups: urban (78.1\%), peri-urban $(87.5 \%)$ and rural (65.2\%). According to LC1 leaders, pigs were slaughtered at pen-side and distributed to trading centres by traders, or taken alive to nearby trading centres and slaughtered at butcheries in all levels of urbanicity. In Kampala, there is a single abattoir that slaughters pigs at Wambizi where a veterinarian inspects pig carcases [35]. The percentages of pig farms selling to Wambizi abattoir in urban $(5.2 \%)$ and periurban areas $(4.5 \%)$ were low and no rural pig farms sold to this abattoir. A few LC1 leaders mentioned local pig abattoirs in and around Kampala; an unofficial abattoir owner in 
Table 4. Sales destinations of the livestock products in the Kampala economic zone

\begin{tabular}{cccc}
\hline & Urban & Peri-urban & Rural \\
\hline Improved breed cattle farm & 109 & 237 & 129 \\
Nearby TC, neighbours & 98 & 237 & 129 \\
Percentage $(95 \%$ CI $)$ & $89.9(82.7-94.6)$ & $100(98.7-100)$ & $100(97.7-100)$ \\
Outside trading centre & 11 & 64 & 12 \\
Percentage $(95 \%$ CI) & $10.1(5.1-17.3)$ & $27.0(21.5-33.1)$ & $9.3(4.9-15.7)$ \\
\hline Cattle farm of any breed & 184 & 352 & 506 \\
Urban abattoirs & 103 & 121 & 67 \\
Percentage $(95 \%$ CI & $56.0(48.5-63.3)$ & $34.7(29.7-39.9)$ & $13.2(10.4-16.5)$ \\
Peri-urban abattoirs & 99 & 344 & 506 \\
Percentage $(95 \%$ CI) & $53.8(46.3-61.2)$ & $98.6(96.7-99.5)$ & $100(99.4-100)$ \\
\hline Pig farm & 503 & 869 & 557 \\
Nearby TC, neighbours & 438 & 719 & 427 \\
Percentage $(95 \%$ CI) & $87.1(83.8-89.9)$ & $82.7(80.1-85.2)$ & $76.7(72.9-80.1)$ \\
Outside trading centre & 393 & 760 & 363 \\
Percentage $(95 \%$ CI) & $78.1(74.3-81.7)$ & $87.5(85.1-89.6)$ & $65.2(61.1-69.1)$ \\
Wambizi Abattoir & 26 & 39 & 0 \\
Percentage $(95 \%$ CI) & $5.2(3.4-7.5)$ & $4.5(3.2-6.1)$ & $0(0.0-0.5)$ \\
\hline Goat farm & 238 & 153 & 335 \\
Distributing in Kampala & 84 & 27 & 87 \\
Percentage $(95 \%$ CI) & $35.3(29.2-42.7)$ & $17.6(12.0-24.6)$ & $26.0(21.4-31.0)$ \\
\hline Broiler farm & 890 & 148 & 43 \\
Nearby trading centre & 806 & 133 & 32 \\
Percentage $(95 \%$ CI) & $90.6(88.4-92.4)$ & $89.9(83.8-94.2)$ & $74.4(58.8-86.5)$ \\
Outside trading centres & 746 & 132 & 21 \\
Percentage $(95 \%$ CI) & $83.8(81.2-86.2)$ & $89.2(83.0-93.7)$ & $48.8(33.3-64.5)$ \\
\hline Layer farm & 264 & 68 & 51 \\
Nearby trading centre & 253 & 32 & 35 \\
Percentage $(95 \%$ CI) & $95.8(92.7-97.9)$ & $47.1(34.8-59.6)$ & $68.6(54.1-80.9)$ \\
Outside trading centres & 210 & 40 & 28 \\
Percentage $(95 \%$ CI) & $79.5(74.2-84.2)$ & $58.8(46.2-70.6)$ & $54.9(40.3-68.9)$ \\
\hline & & & \\
\hline & & & \\
\hline
\end{tabular}

Table 5. The numbers of patients and the numbers of households in the studied LC1s according to the level of urbanisation where they reside

\begin{tabular}{lcccc}
\hline & Urban & Peri-urban & Rural & Total \\
\hline GI infections & 231 & 8 & 5 & 244 \\
& $(94.7)$ & $(3.3)$ & $(2.0)$ & \\
\hline Brucellosis & 276 & 19 & 2 & 297 \\
& $(92.9)$ & $(6.4)$ & $(0.7)$ & \\
\hline Abdominal tuberculosis & 58 & 12 & 3 & 73 \\
& $(79.5)$ & $(16.4)$ & $(4.1)$ & \\
\hline Households in studied & 36,184 & 5,294 & 3,484 & 44,962 \\
LC1s & $(80.5)$ & $(11.8)$ & $(7.7)$ & \\
\hline
\end{tabular}

The percentages are shown in parentheses.

Nsambya, central Kampala confirmed that his pork was not inspected.

Sales of goats, through traders, to outside trading centres and abattoirs were not common in urban $(35.3 \%)$, periurban $(17.6 \%)$ and rural areas $(26.0 \%)$ as compared with other livestock species. The main purposes of goat farming was for home consumption, for special occasions such as Christmas and Easter and for use as assets, especially for children's school fees. For home consumption, goats are slaughtered either by butchers in trading centres or at home without meat inspection by veterinarians.

The broiler and layer value chains were well established in urban and peri-urban areas; large proportion of farms participated sales outside trading centres. The purpose of indigenous chicken keeping was mainly for home consumption.

Level of urbanisation where patients reside: Table 5 shows the numbers of GI infections, brucellosis and abdominal TB patients and the numbers of households in the interviewed LC1s according to the level of urbanisation where 
they resided. GI infections cases and Brucella plate agglutination test positive cases were traced from outpatient registration book in 2005, and between June 2004 and May 2006, respectively- only traced cases were used for the analysis. Abdominal TB cases were traced from the TB ward inpatient records. It should be noted that abdominal TB cases were not necessarily caused by $M$. bovis. Epilepsy cases were not shown here because epilepsy cannot necessarily be caused by cysticercosis and the relationship between them was not assumed to be strong enough to serve for analysis.

The majority of the patients of all the diseases were from urban areas and the proportions matched with the numbers of households in the studied LC1s, rather than the numbers of livestock farming households.

Identification of the most important zoonoses related to livestock farming: Although behaviour related to cooking and consumption of animal source foods were not studied in the present study, livestock farming systems and value chain analysis suggested that there are significant chance of exposure to livestock farming-related zoonotic pathogens (common practices of poultry farming, sales of raw milk and absence of pork and goats meat inspection). Considering the severity of the diseases, animal source food-borne gastroenteritis, brucellosis, M. bovis TB and NCC were identified as the most important livestock farming-related zoonoses in the Kampala economic zone (see Table 2 and Fig. 3c). Among these, animal source food-borne gastroenteritis and brucellosis were estimated to be highly prevalent.

\section{DISCUSSION}

The present study was conducted to identify livestock farming-related important zoonotic diseases in the Kampala economic zone in order to assess the risks from urban and peri-urban livestock farming. Several studies had been conducted in this zone related to this issue: Brucella $[26,31]$ and $E$ coli O-157: H7 [17] in milk, M. bovis in cattle carcass in an abattoir [2] and Taenia solium cysticercosis in pork carcasses in abattoirs [22], and these diseases were also identified as important zoonoses in the present study.

Poor correlation between spatial distribution of livestock farmers and their animals in peri-urban and rural areas and distribution of human population and patients with selected diseases in urban areas suggested that the majority of livestock farming-related zoonoses were food-borne and were caused by informally-marketed foods. For the assessment of risks from urban and peri-urban livestock farming, there is often a pitfall that the risks flowing into cities from outside the economic zone are neglected. In the case of brucellosis in Kampala, a large proportion of raw milk contaminated with Brucella was carried from Mbarara, the largest dairy production areas in Uganda [26]. Herd size in peri-urban areas was not different from urban and rural areas; this also suggested that peri-urban livestock farming in Kampala had not been intensified very much and instead, strong rural-urban linkages has been established. Future studies on urban and peri-urban food-borne zoonoses should incorporate a value chain analysis because of this reason. Regarding the risk of infection from direct contact with animals/birds, poultry farming has the highest risk; it was found to be most popular in and around Kampala. Although previous studies reported that rearing chicken was not associated with the prevalence of enteric illness in Kampala [7], risk of the infection with H5N1 highly pathogenic avian influenza (HPAI) in Kampala was potentially very high and it could pose a serious health risk. The case-fatality $(\mathrm{CF})$ rate of HPAI was estimated to $14-33 \%$ under pandemic conditions [24] and HPAI is known to be transmitted rapidly [37].

The present study provided a useful framework for identifying livestock farming-related important zoonoses in and around cities; however this method has limitations: (i) a great number of zoonoses might be missed among outpatients whose symptom was reported (ii) clinical diagnoses cannot indicate specific zoonoses such as M. bovis TB and cysticercosis and (iii) unless cooking and consumption behaviour at the household level is studied, risks through the value chain cannot be determined. There are reports on consumption behaviour relating to raw eggs [7] and risk mitigation strategies for milk consumption [16] in Kampala. Such behavioural studies for other foods could contribute towards a better understanding of food safety in Kampala.

In the present study, animal source food-borne gastroenteritis was the most prevalent zoonosis in Kampala. We used the proportion of food-borne illness out of GI infections in U.S.A. as a parameter to estimate food-borne gastroenteritis cases; however considering the difference of food hygiene situation between U.S.A. and Uganda, a much larger proportion of GI infections could have been caused by animal source foods. There are many types of animal source food-borne gastroenteritis and detailed studies are needed. The number of $M$. bovis TB cases was estimated to be low. However, considering the many brucellosis cases diagnosed and the high herd prevalence $(74.1 \%)$ of $M$. bovis in Mbarara [11], there could be a much larger number of $M$. bovis TB cases due to consumption of milk and dairy products. In Kampala, it has been reported that $97 \%$ of urban consumers, both adults and children, boiled milk with tea prior to consumption [17]. However the problem of consumption of unpasteurized milk and dairy products in Kampala should not be overlooked. Also, although our study showed that almost all the cattle carcasses were slaughtered in abattoirs under veterinary inspection, it has been reported that none of the carcasses with TB-like lesions were condemned in a slaughterhouse in Kampala where 11 cultures of $M$. bovis were recovered from 87 TB-like lesions [2]. The number of neuro-cysticercosis cases was also estimated to be low although Taenia solium is known to be prevalent in Uganda [22]. Considering the low meat inspection rate of pig carcasses and the popularity of pork in Kampala [35], taeniasis may be common in Kampala and many cysticercosis cases could have been missed.

The present study identified four diseases: animal source food-borne gastroenteritis, brucellosis, M. bovis tuberculo- 
sis and T. solium cysticercosis as the most important livestock farming-related zoonoses in the Kampala economic zone. However the method used in the study has its limitations and more detailed studies are needed, especially on different types of GI infections, $M$. bovis TB and neuro-cysticercosis for a better understanding of livestock farmingrelated zoonoses in Kampala.

ACKNOWLEDGMENTS. We would like to thank the U.K. Department for International Development (DFID) Animal Health Programme (KM, EMF, MCE, SCW) for support for this work, although the views expressed are not necessarily those of DFID. KM thanks the Japan International Cooperation Agency (JICA) for research grant support. EMF is funded by the Wellcome Trust (085308). The funders had no role in study design, data collection and analysis, decision to publish, or preparation of the manuscript. We are grateful to Mulago National Referral Hospital, Uganda, especially the Medical Record Division for the great assistance on the collection of necessary information. We also are grateful to Joseph Sempijja for assistance with field-work. Many thanks go to the respondents to the interviews in the Kampala economic zone.

\section{REFERENCES}

1. Adak, G. K., Meakins, S. M., Yip, H., Lopman, B. A. and O'Brien, S. J. 2005. Disease risks from foods, England and Wales, 1996-2000. Emerg. Infect. Dis. 11: 365-372.

2. Asiimwe, B. B., Asiimwe, J., Kallenius, G., Ashaba, F. K., Ghebremichael, S., Joloba, M. and Koivula, T. 2009. Molecular characterisation of Mycobacterium bovis isolates from cattle carcasses at a city slaughterhouse in Uganda. Vet. Rec. 164: 655-658.

3. Blocher, J., Schmutzhard, E., Gotwald, T., Auer, H., Matuja, W. and Winkler, A. 2007. Epilepsy and neurocysticercosis in northern Tanzania. Trop. Med. Int. Health 12: 90.

4. Box, G. E. P. and Cox, D. R. 1964. An analysis of transformations. J. R. Stat. Soc. Series. B Stat. Methodol. 26: 211-246.

5. Chin, J. 2000. Control of Communicable Diseases Manual, 17th Ed., American Public Health Association, Washington.

6. Cosivi, O., Grange, J. M., Daborn, C. J., Raviglione, M. C., Fujikura, T., Cousins, D., Robinson, R. A., Huchzermeyer, H. F., de Kantor, I. and Meslin, F. X. 1998. Zoonotic tuberculosis due to Mycobacterium bovis in developing countries. Emerg. Infect. Dis. 4: 59-70.

7. Dimoulas, P., Waltner-Toews, D., Humphries, S. and Nasinyama, G. W. 2008. Household risk factors associated with chicken rearing and food consumption in Kampala. pp 177191. In: Healthy City Harvests: Generating Evidence to Guide Policy on Urban Agriculture (Cole, D. C., Lee-Smith, D. and Nasunyama, G. W. eds.), International Potato Center (CIP), Lima and Makerere University Press, Kampala.

8. Ellis, F. and Sumberg, J. 1998. Food production, urban areas and policy responses. World Dev. 26: 213-225.

9. FAO. FAOSTAT: the statistical database of FAO [cited 2010 February 1]. Available from http://faostat.fao.org/default.aspx

10. FAO. 2000. Urban and Peri-urban Agriculture, Food and Agriculture Organization of the United Nations, Rome.

11. Faye, B., Castel, V., Lesnoff, M., Rutabinda, D. and Dhalwa, J.
2005. Tuberculosis and brucellosis prevalence survey on dairy cattle in Mbarara milk basin (Uganda). Prev. Vet. Med. 67: 267-281.

12. Fèvre, E. M., Kaboyo, R. W., Persson, V., Edelsten, M., Coleman, P. G. and Cleaveland, S. 2005. The epidemiology of animal bite injuries in Uganda and projections of the burden of rabies. Trop. Med. Int. Health 10: 790-798.

13. Flint, J. A., Duynhoven, Y. T. V., Angulo, F. J., DeLong, S. M., Braun, P., Kirk, M., Scallan, E., Fitzgerald, M., Adak, G. K., Sockett, P., Ellis, A., Hall, G., Gargouri, N., Walke, H. and Braam, P. 2005. Estimating the burden of acute gastroenteritis, foodborne disease, and pathogens commonly transmitted by food: an international review. Clin. Infect. Dis. 41: 698-704.

14. Flynn, K. 1999. An Overview of Public Health and Urban Agriculture: Water, Soil and Crop Contamination \& Emerging Urban Zoonosis. Cities Feeding People series vol 30, IDRC, Ottawa, Canada.

15. Gall, D. and Nielsen, K. 2004. Serological diagnosis of bovine brucellosis: a review of test performance and cost comparison. Rev. Sci. Tec. 23: 989-1002.

16. Grace, D., Nasinyama, G. W., Randolph, T. F., Mwiine, F. and Kang'ethe, E. 2008. City dairying in Kampala: integrating benefits and harms. pp. 193-210. In: Healthy City Harvests: Generating Evidence to Guide Policy on Urban Agriculture, (Cole, D. C., Lee-Smith, D. and Nasunyama, G. W. eds.), International Potato Center (CIP), Lima and Makerere University Press, Kampala.

17. Grace, D., Omore, A., Randolph, T., Kang'ethe, E., Nasinyama, G. W. and Mohammed, H. O. 2008. Risk assessment for Escherichia coli O157:H7 in marketed unpasteurized milk in selected East African countries. J. Food. Prot. 71: 257-263.

18. Havelaar, A. H., Rosse, F. V., Bucura, C., Toetenel, M. A., Haagsma, J. A., Kurowicka, D., Heesterbeek, J. H. A. P., Speybroeck, N., Langelaar, M. F. M., Giessen, J. W. B. V. D., Cooke, R. M. and Braks, M. A. H. 2010. Prioritizing emerging Zoonoses in The Netherlands. PLoS ONE 5: e13965.

19. Imhoff, B., Morse, D., Shiferaw, B., Hawkins, M., Bugia, D., Lance-Parker, S., Hadler, J., Medus, C., Kennedy, M., Moore, M. R. and van Gilder, T. 2004. Burden of self-reported acute diarrheal illness in FoodNet surveillance areas, 1998-1999. Clin. Infect. Dis. 38: S203-211.

20. Kazwala, R. R., Daborn, C. J., Sharp, J. M., Kambarage, D. M., Jiwa, S. F. and Mbembati, N. A. 2001. Isolation of Mycobacterium bovis from human cases of cervical adenitis in Tanzania: a cause for concern? Int. J. Tuberc. Lung Dis. 5: 87-91.

21. King'ori, P. 2004. Assessment of urban and peri-urban agriculture research in the Centres of the Consultative Group on International Agricultural Research (CGIAR) in Sub-Saharan Africa. pp. 1-3. In: Urban Harvest Paper Series, no.1., International Potato Center (CIP), Lima.

22. Kisakye, J. J. M. and Masaba, S. C. 2002. Cysticercus cellulosae in pigs slaughtered in and around Kampala city. Uganda J. Agric. Sci. 7: 23-24.

23. Lee-Smith, D., Azuba, S. M., Musisi, J. M., Kaweesa, M. and Nasinyama, G. W. 2008. The story of the health coordinating committee, KUFSALCC and the urban agriculture ordinances. pp. 219-229. In: Healthy City Harvests: Generating Evidence to Guide Policy on Urban Agriculture (Cole, D. C., Lee-Smith, D. and Nasunyama, G. W. eds.), International Potato Center (CIP), Lima and Makerere University Press, Kampala.

24. Li, F. C. K., Choi, B. C. K., Sly, T. and Pak, A. W. P. 2008. Finding the real case-fatality rate of $\mathrm{H} 5 \mathrm{~N} 1$ avian influenza. $J$. Epidemiol. Community Health 62: 555-559. 
25. Makita, K., Fèvre, E. M., Waiswa, C., Bronsvoort, B. M. D. C., Eisler, M. C. and Welburn, S. C. 2010. Population-dynamics focussed rapid rural mapping and characterisation of the periurban interface of Kampala, Uganda. Land Use Policy 27: 888-897.

26. Makita, K., Fèvre, E. M., Waiswa, C., Eisler, M. C. and Welburn, S.C. 2010. How human brucellosis incidence in urban Kampala can be reduced most efficiently? A stochastic risk assessment of informally-marketed milk. PLOS ONE 5: e14188.

27. Mariner, J. C. and Paskin, R. 2000. Manual on participatory epidemiology- Method for the collection of action-oriented epidemiological intelligence. FAO Animal Health Manual 10 [cited 2006 March 1]. Available from http://www.fao.org/ DOCREP/003/x8833E/x8833E00.htm

28. Matsubayashi, K., Kang, J. H., Sakata, H., Takahashi, K., Shindo, M., Kato, M., Sato, S., Kato, T., Noshimori, H., Tsuji, K., Maguchi, H., Yoshida, J., Maekubo, H., Mishiro, S. and Ikeda, H. 2008. A case of transfusion-transmitted hepatitis E caused by blood from a donor infected with hepatitis A virus via zoonotic food-borne route. Transfusion 48: 1368-1375.

29. Maxwell, D. G. 1995. Alternative food security strategy: a household analysis of urban agriculture in Kampala. World Dev. 23: 1669-1681.

30. Mead, P. S., Slustker, L., Diets, V., McCaig, L. F., Bresee, J. S., Shapiro, C., Griffin, P. M. and Tauxe, R. V. 1999. Foodrelated illness and death in the United States. Emerg. Infect. Dis. 5: 607-624.

31. Mwiine, F. N. 2004. Benefits and health risks associated with milk and cattle raised in urban and peri-urban areas of Kampala City, Master Thesis, Makerere University, Kampala.

32. Nabulo, G., Oryem-Origa, H., Nasynyama, G. W., Cole, D. C. and Diamond, M. 2008. Assessment of heavy metal contamination of food crops in wetlands and from vehicle emissions. pp. 111-131 In: Healthy City Harvests: Generating Evidence to Guide Policy on Urban Agriculture (Cole, D. C., Lee-Smith, D. and Nasunyama, G. W. eds.), International Potato Center (CIP), Lima and Makerere University Press, Kampala.

33. Park, S. I. and Giannella, R. A. 1993. Approach to the adult patient with acute diarrhea. pp. 483-497. In: Acute Infectious Diarrhea, Gastroenterology Clinics of North America (Giannella, R.A. ED.), W.B. Saunders Company, Philadelphia.

34. Pavio, N., Meng, X. J. and Renou, C. 2010. Zoonotic hepatitis E: animal reservoirs and emerging risks. Vet. Res. 41:46.

35. Phiri, I. K., Ngowi, H., Afonso, S., Matenga, E., Boa, M., Mukaratirwa, S., Githigia, S., Saimo, M., Sikasunge, C. and Maingi, N. 2003. The emergence of Taenia solium cysticercosis in Eastern and Southern Africa as a serious agricultural problem and public health risk. Acta Trop. 87: 13-23.
36. Sebastian, R., Lubowa, A., Yeudall, F., Cole, D. C. and Ibrahim, S. 2008. The association between household food security and urban farming in Kampala. pp. 69-87. In: Healthy City Harvests: Generating Evidence to Guide Policy on Urban Agriculture (Cole, D. C., Lee-Smith, D. and Nasunyama, G. W. eds.), International Potato Center (CIP), Lima and Makerere University Press, Kampala.

37. Seck, B., Squarzoni, C. and Litamoi, J. 2007. Experience in control of avian influenza in Africa. Dev. Biol. (Basel) 130: $45-52$.

38. Serani, S., Nasynyama, G. W., Nabulo, G., Lubowa, A. and Makoha, M. 2008. Biological hazards associated with vegetables grown on untreated sewage-watered soils in Kampala. pp. 151-169. In: Healthy city harvests: Generating Evidence to Guide Policy on Urban Agriculture (Cole, D. C., Lee-Smith, D. and Nasunyama, G. W. eds.), International Potato Center (CIP), Lima and Makerere University Press, Kampala.

39. Sumberg, J. 1999. The Dar es Salaam milk system: dynamics of change and sustainability. Habitat Int. 23: 189-200.

40. Taylor, L. H., Latham, S. M. and Woolhouse, M. E. 2001. Risk factors for human disease emergence. Philos. Trans. R. Soc. Lond. B Biol. Sci. 356: 983-989.

41. United Nations. 2004. Republic of Uganda. Public Administration Country Profile. Division for Public Administration and Development Management (DPADM), Department of Economic and Social Affaires (DESA), United Nations, New York.

42. White, A. C. J. 2000. Neurocysticercosis: updates on epidemiology, pathogenesis and management. Annu. Rev. Med. 51: $187-206$.

43. WHO. 1959. Zoonoses: Second Report of the Joint WHO/FAO expert committee, World Health Organization, Geneva.

44. WHO. 2000. Hepatitis A. Department of Communicable Disease Surveillance and Response, WHO, Geneva.

45. WHO. 2007. International Statistical Classification of Diseases and Related Health Problems10th Revision Version for 2007, WHO, Geneva.

46. WHO. 2008. The Global Burden of Disease: 2004 update. WHO Library Cataloguing-in-Publication Data, WHO, Geneva.

47. WHO. Tetanus [cited 2010 March 15]. Available from http:// www.who.int/topics/tetanus/en/

48. Yeudall, F., Sebastian, R., Lubowa, A., Kikafunda, J., Cole, D. C. and Ibrahim, S. 2008. Nutritional security of children of urban farmers. pp. 89-103. In: Healthy City Harvests: Generating Evidence to Guide Policy on Urban Agriculture (Cole, D. C., Lee-Smith, D. and Nasunyama, G. W. eds.), International Potato Center (CIP), Lima and Makerere University Press, Kampala. 